\title{
Characterizing Spatial Variations of Urban Growth Patterns in Beijing, China through Spatial Analysis and Geovisualization
}

\author{
Ting Liu ${ }^{\mathrm{a}}{ }^{*}$, Xiaojun Yang ${ }^{\mathrm{b}}$ \\ ${ }^{a}$ Department of Geography and Environmental Studies, Northeastern Illinois University, Chicago, IL 60625, USA, tliu1@neiu.edu \\ ${ }^{b}$ Department of Geography, Florida State University, Tallahassee, FL 32306, USA,xyang@fsu.edu \\ * Corresponding author
}

Keywords: Urban Growth, Geovisualization, Spatial Analysis, GIS, Beijing

\begin{abstract}
:
As the capital city and one of the largest cities of China, Beijing has experienced rapid urban growth in the past several decades. Despite the numerous research efforts of monitoring the spatiotemporal urban growth patterns in Beijing, there is a lack of consensus and comparable results for theory development or decision-making.

This paper presents a systematic approach of characterizing urban growth patterns in Beijing through spatial analysis and geovisualization. Specifically, we focus on characterizing the different dimensions of urban growth across scales, including density, continuity, direction, and centrality (Galster et al. 2001). We first derive general land cover information in Beijing from satellite imagery for the years of 1998, 2008, and 2018. The urban extent of Beijing is extracted for each year to be used for further analysis. We then characterize the urban growth patterns through various geovisualization and spatial analysis techniques at both the metropolitan level and the local/cell level (Table 1).
\end{abstract}

Table 1. Spatial analysis and geovisualization techniques used for characterizing urban growth patterns

\begin{tabular}{|c|c|c|}
\hline $\begin{array}{l}\text { Urban Growth } \\
\text { Dimensions }\end{array}$ & Metropolitan level & Local level \\
\hline Density & $\begin{array}{l}\text { Percent development measured for each } \\
\text { neighborhood and district; } \\
\text { Compare measurements across the functional } \\
\text { zones, i.e., urban core, extensive urban, new } \\
\text { urban, and ecological conservation zone }\end{array}$ & \multirow[t]{2}{*}{$\begin{array}{l}\text { GIS-based moving windows analysis and } \\
\text { contour mapping }\end{array}$} \\
\hline Continuity & $\begin{array}{l}\text { Landscape pattern metrics } \\
\text { Compare measurements across the functional } \\
\text { zones }\end{array}$ & \\
\hline Direction & $\begin{array}{l}\text { Sector-based measurements } \\
\text { Compare measurements across the functional } \\
\text { zones }\end{array}$ & \multirow[t]{2}{*}{$\begin{array}{l}\text { Geometric measurements based on the } \\
\text { contour analysis }\end{array}$} \\
\hline Centrality & Cluster analysis (Local Moran’s I) & \\
\hline
\end{tabular}

At the metropolitan level, we present the general trends of urban growth patterns in Beijing through landscape pattern metrics and spatial statistics. In addition, we compare the measurements of density, continuity and direction across the four functional zones in Beijing, i.e., urban core, extensive urban, new urban, and ecological conservation zone. The result reveals the regional variations and the underlying processes of urban growth in the Beijing metropolitan area. At the local level, we measure the spatial variations of urban growth patterns using a GIS-based moving windows analysis. As the moving window passes over the landscape, each calculated metrics is returned to the focal cell. This creates a surface representation of the selected metrics, which enables the creation of a contour map. The distribution of the contours delineates the spatial variations of urban growth at a finer scale. The developed approach can be applied to urban studies of other geographic areas, which will eventually lead to a comparative study of urban development. 